Arab World English Journal (AWEJ) Special Issue on Covid 19 Challenges April 2021

DOI: https://dx.doi.org/10.24093/awej/covid.23

\title{
Indonesian Freshmen's Challenges in Collaborative Learning during COVID-19 Pandemic:A Reflection of a Procedural Writing Class
}

\author{
Listyani \\ English Language Education Program (ELEP) \\ Faculty of Language and Arts (FLA) \\ Universitas Kristen Satya Wacana \\ Salatiga, Indonesia
}

Received: $3 / 5 / 2021$

Accepted: 4/12/2021

Published: 4/26/2021

\section{Abstract}

One of the impacts of the COVID-19 pandemic in the world of education is the implementation of online learning. Almost all teaching/learning activities must be changed and adjusted with the virtual classes. One among other activities commonly done in an English language education program is group work or collaborative work between or among students. Due to the pandemic situation, this particular activity should also be done online. This study aims to describe freshmen's perspectives on collaborative work done in a Procedural Writing class. The teacher of the writing class randomly paired the students to work collaboratively. There is only one research question in this study: What challenges do Procedural Writing students experience in doing collaborative learning during the pandemic COVID 19? Data were derived from reflections that fourteen (14) Procedural Writing students at an English Language Education Program (ELEP), UKSW, Indonesia, wrote in the sixth week of Semester II/ 2020-2021 academic year, and from interviews with two participants who said that they were not happy with collaborative learning. Findings showed that in general, the freshmen felt that collaborative work helped them write better, they got more ideas, helped in their grammar, and exchanged knowledge. Only two students felt unhappy due to misunderstanding and ideas which were not delivered successfully. This study will hopefully be useful for writing teachers, practitioners in education, as well as students so that they will have a wider horizon of what writing students feel and experience in collaborative learning during this pandemic era.

Keywords: freshmen, challenges, collaborative learning, Procedural Writing, COVID-19, pandemic

Cite as: Listyani, L. (2021). Indonesian Freshmen's Challenges in Collaborative Learning during COVID-19 Pandemic:A Reflection of a Procedural Writing Class . Arab World English Journal (AWEJ) Special Issue on Covid 19 Challenges April 2021 (1) 307-31.

DOI: https://dx.doi.org/10.24093/awej/covid.23 
Arab World English Journal (AWEJ) Special Issue on Covid 19 Challenges April 2021

Indonesian Freshmen's Challenges in Collaborative Learning during COVID-19

Listyani

\section{Introduction}

Online learning is a massive revolutionary in many companies. Up to $90 \%$ of corporations use online learning by the year 2020. In 1995, it was only 4\%. The E-learning market is predicted to grow another 8\% in 2026 (Anna, 2019). The world has been drastically changing in many aspects for the past year. It was the outbreak of Coronavirus which caused all these changes. The world seemed to start a new era in which the digital and virtual world is now rising and becoming the top priority. The world of education is not an exception. All teaching/ learning processes and activities have shifted from offline to online ones.

According to Higley (2018), online learning environments are different from traditional classroom learning opportunities. Online learning fosters additional learning experiences where learners can interact, collaborate, and take ownership of their own learning. Cooperative work has also changed in its form. It cannot be done directly anymore. Students have to meet virtually. Many teachers still assign students to work collaboratively despite the pandemic COVID because cooperative learning including group work can give many benefits to students. Laal and Ghodsi (2012) mentioned that through collaborative learning, students learn to solve a problem, complete a task, or complete a project.

Considering the positive values of collaborative work, like understanding and appreciating others' opinions as well as negotiation of meaning, the researcher perceived the need to conduct this present study. The rationale underlying this study is that it is necessary to describe and share what freshmen's perspectives are about collaborative learning during pandemic COVID. This study will hopefully add its value and significance as it will shed a light to research under the area of collaborative learning and enrich more literature in that field.

This study is guided by one research question: What challenges do Procedural Writing students experience in doing collaborative learning during the pandemic COVID 19? This research is therefore aimed to describe what Procedural Writing students experience in doing collaborative learning during the pandemic COVID 19. It is hoped that the results of this study can help English teachers in the future to implement and maximize the use of collaborative learning in the classroom to improve students' procedural essays. Hopefully, EFL writing teachers will still see the benefits of collaborative learning. Students can hopefully feel the advantages as well.

\section{Literature Review \\ Online Learning}

Over the past year, since the outbreak of Coronavirus, many changes have happened in the field of education. One way to keep the teaching and learning process going on is through online learning. Online or distance learning has been very popular these days. Almost all systems are shifting from direct or face-to-face activities to online ones. All learners should move to an area where all teaching-learning processes are digitally and virtually done. Students of all levels of education have to adapt and adjust themselves to this so-called virtual distant education.

Rudghhoff (2006)-mentioned that online education or learning plays an important role in language learning and teaching (as cited in Cinganotto, 2019). In line with Rudghhoff, Song, Rice, and Oh (2019) also argued that online learning environments can be well understood as a 


\section{Arab World English Journal (AWEJ) Special Issue on Covid 19 Challenges April 2021}

Indonesian Freshmen's Challenges in Collaborative Learning during COVID-19

Listyani

phenomenon of many facets or simply said, a phenomenon affected by many aspects. Purarjomandlangrudi and Chen (2019) believed that online education is an educational medium that enables both learners and teachers to interact with one another. Nonetheless, these learners and teachers are located in different geographical locations. They can meet virtually at the same time, or at different times.

Student interaction becomes one of the most important factors related to online learning, according to Berg (2019). Teachers should ensure that all students are active and engaged, can create their own knowledge, and can reach a high level of achievement. Interaction in distance learning has been divided into three categories. They are interacting with content; interaction with the instructor; and interaction with peers (Moore, 1989, as cited in Berg, 2019). Bouhnik and Marcus (2006) added the fourth category of interaction. It is interaction with the system (as cited in Berg, 2019).

Just like what a famous saying mentions, every coin has two sides; it means that everything has its strengths and weaknesses. Online education is not an exception. Hameed, Taiar, O'Leary and Kaynge (2018) claimed that there are many challenges of conducting online distance learning. A potential lack of the required technology is the first challenge. The examples are Internet access, laptops, or desktop computers. This further deals with the fees of subscribing to these online learning templates. Then, there can also be problems around the need to have technical support, and logistic issues. These technical problems can cause bad internet access. In turn, it will affect the functioning of the virtual team. The choice of an experienced online platform must, therefore, be considered carefully.

Secondly, Hameed, Taiar, O'Leary, and Kaynge (2018) explained that there may be ethical issues about the protection of confidentiality in these sessions. This requires knowledge of the relevant professional requirements, like the tutor team, for example. Other than that, the student-teacher relationship has traditionally been trademarked by direct face-to-face or direct contact and being present at the same time and place, that is, in the classrooms surrounded by walls. Consequently, learners and educators may be less satisfied with online learning. For these reasons, the concept of blended learning, which is an integration of online learning with the faceto-face learning experience, has been developed to overcome the limitations of stand-alone online or face-to-face learning and has been found effective and applicable in various settings.

The third challenge is that all kinds of distance online learning programs must understand and support the existence of the training provision as well as arrangements, both in the classroom and in the workplace. This means liaison and cooperation with the training providers and institutions are required. Liauw, Huang, and Cheng (2007) added that the base of learning activity in online learning is learner autonomy and interactive learning actions (as cited in Omar, Hassan \& Atan, 2012).

Since the first quarter of 2020, the world "has been forced" to apply the online teachinglearning process due to the pandemic. Whether they were ready or not or whether they liked it or not, they had to shift from the ordinary face-to-face Teaching/Learning Process (TLP) to the virtual, digital one. Four-wall classrooms have been substituted by virtual classrooms without walls. There has been a massive change from a normal offline TLP to the online one. With these 


\section{Arab World English Journal (AWEJ) Special Issue on Covid 19 Challenges April 2021}

Indonesian Freshmen's Challenges in Collaborative Learning during COVID-19

Listyani

great changes, all parties, the government, teachers, parents, as well as students have to adapt to the new system. All learning activities have been designed in such a way that they can be done virtually. This includes collaborative work which should also be done online. Not much research has been done in this area, which therefore creates a gap between the ideal condition of collaborative learning and the reality experienced by foreign language learners. Discussed below is the implementation of online collaborative learning during the pandemic.

\section{Collaborative Learning}

Working collaboratively with other people may not be easy. There can be different ideas, different opinions, as well as difficulties in interrelating ideas. Misunderstanding often happens, leading to uneasiness between and among learners. However, there are many positive sides of collaborative learning that can be explored. According to Laal and Ghodsi (2011), one benefit of using collaborative learning in the classroom is that it involves students, and they will absolutely be more actively engaged in classroom activities. Students are also "forced" to communicate and interact with others when playing games.

In spite of the benefits that can be felt from collaborative learning, there are also challenges that arise during the implementation. Firstly, all learners have different styles of learning. There are students who like to work in groups, but there are also learners who dislike it. Not everyone can work with others successfully. Secondly, students who do not like working in groups will participate less because of their lack of confidence or low self-esteem, which possibly leads to inferiority to their peer students. In order to suit the students' characteristics, while they are still in the transitional phase from junior to senior high school and they still like to play, teachers need to be aware of the different kinds of approaches for activities in the classroom.

Laal and Ghodsi (2011) defined collaborative learning as an educational approach in teaching and learning where the learners work together in a group in order to complete a task, solve a problem, or create a product. Gerlach (1994) pointed out that collaborative learning is based on the participants' interaction through their conversations when the learning occurs (as cited in Bishnoi, 2017). Problems, questions, or the challenge to create something all drive the group activity, and everyone is supposed to be actively participating. It a situation where two or more people learn together.

Methods like cooperative learning, group learning, peer learning, learning community, and constructive learning are often used interchangeably with collaborative learning (Campbell $\& \mathrm{Li}, 2006$ ). Collaborative learning is a kind of method that has a positive impact on students. It is a powerful tool in learning and has the potential to be used in ways that can make a great impact on classroom language learning. According to Overtoom (2001), collaborative learning has benefits in enhancing the students' employability skills because it supports active learning and self-discovery.

Another expert, Hedge (2000), further claimed that anytime students of different performance levels work together in one group, they will be responsible for their peers' learning process instead of merely being accountable for their own interests. In collaborative learning, the ideas and information shared by the students are a valuable learning source for every student in 


\section{Arab World English Journal (AWEJ) Special Issue on Covid 19 Challenges April 2021}

Indonesian Freshmen's Challenges in Collaborative Learning during COVID-19

Listyani

the class. The interactions among the participants in a group, such as feedback or revisions, are a means of identifying strengths and weaknesses to improve performance and even to develop speaking skills. Many researchers have conducted studies on how collaborative learning provides benefits - especially in teaching speaking. However, not much has been done in the area of online collaborative learning.

Another study by Pattanpichet (2011) found a surprising fact that working in groups can grow familiarity and friendships among students. When collaborative learning is used in large classrooms such as arranging students into group work, it helps to create an atmosphere or habit of sharing knowledge. With the help of collaborative learning, students also learn to work in a team. This can help them develop their social skills which will be useful for their work environment in the future.

Higley (2018) argued that online collaborative learning should be maintained. Collaborative learning rooted in constructivism. It views learning as a process, learners actively engage in new ideas through collaborative grouping situations. Still, according to Higley, constructivism is a good theoretical framework for E-Learning considering that it guarantees that learning happens among all learners. Through collaborative learning, all learners are actively engaged.

In line with Higley, McLeod (2019) also explained the idea of constructivism. It states that learners construct meaning through active engagement with the world. They do this through experiments or real-world problem-solving. Vygotsky (1978) believed that the community plays an essential role in the process of meaning-making (as cited in McLeod, 2019). Still, according to Vygotsky the environment where children grow up will influence their way of thinking and what they think about (as cited in McLeod, 2019). Therefore, all teaching and learning is a matter of sharing and negotiating the "socially-constituted knowledge" (Vygotsky, as cited in McLeod, 2019). It is within the zone of proximal development that children and their peers construct knowledge.

\section{Methods}

This study was conducted in Semester II, 2020/2021 academic year, in English Language Education Program (ELEP), in UKSW, a private university in Central Java Indonesia. Data from this study were derived from fourteen (14) students' reflections submitted online to a learning management system on February 20, 2021. Online interviews through WhatsApp call on March 1, 2021, were also conducted with two students. In the sixth week of the semester, after they experienced collaborative work twice with their peer students, they were asked to write their reflections on what they thought of the collaborative work in that particular class. Two students were then interviewed for the sake of data triangulation.

\section{Participants}

The participants in this study were fourteen (14) freshmen who took Procedural Writing class, group C. Their age range was between 19 and 20 years old. There were five male and nine female students. These students were in the second semester of their college years. They entered the study program in 2020. It means that since the beginning of their study up to the time the research was conducted, they had never had offline classes. Altogether there were 42 students of 


\section{Arab World English Journal (AWEJ) Special Issue on Covid 19 Challenges April 2021}

Indonesian Freshmen's Challenges in Collaborative Learning during COVID-19

Listyani

parallel Procedural Writing classes. The class taught by the researcher was group C. All the students in group $\mathrm{C}$ were involved as research participants. The sampling technique is thus considered convenience sampling since the researcher was also the teacher of group C.

\section{Instruments}

This current study only used two research instruments, the first one is guided reflections submitted on February 20, 2021, and the other is online interview protocol via WhatsApp call on March 1, 2021. There is only one guiding question for the reflection: How did you feel about the collaborative work with your peer students? Was it easy? Was it difficult?

The second instrument is the in-depth interview. The interview questions are confirmation for unclear statements, starting with What do you mean by...please explain. All participants were allowed to answer either in English or Indonesian, both in the reflections and online interviews. All of them used English for the reflections, and Indonesian for the interviews, considering that this was to avoid misunderstanding. Besides that, they did not have to think of the English grammar and vocabulary.

\section{Research Procedures}

Procedural Writing class is a compulsory subject to be taken by the second-semester students of an ELEP, in a private university in Central Java. It is the second writing class that they have to take, after the Creative Writing class. It is a writing course in which students are taught to write procedural essays. The objective of the course is to make students able to write pieces of writing showing series of procedures (ELEP, 2021). Altogether, they have to write four procedural essays; the first three of which are written collaboratively. The first writing that the participants had to make was one paragraph only, the second a three-paragraph essay, the third a fiveparagraph essay and the fourth was an individual five-paragraph essay. The fourteen participants in this study were second-semester freshmen.

\section{Results}

Throughout the semester, the participants had to write pieces of writing collaboratively. Data were taken after they wrote their second essays, which means that they had experienced writing essays twice with their peers. All of the participants admitted that they had online discussions via WhatsApp messages. Shown below is Table one consisting of the fourteen Procedural Writing students' opinions on collaborative learning.

Table 1. Procedural students' opinions on collaborative learning

\begin{tabular}{|c|l|}
\hline $\begin{array}{c}\text { Students' } \\
\text { Initials }\end{array}$ & \multicolumn{1}{c|}{ Students' Opinions } \\
\hline $\begin{array}{c}\text { A } \\
(\mathrm{M})\end{array}$ & $\begin{array}{l}\text { First, there was no problem. We were having an online discussion. The problem } \\
\text { dealt with a cellular network and the ideas that we had, but everything was still } \\
\text { going on well till the work was done. }\end{array}$ \\
\hline B & $\begin{array}{l}\text { I could have more ideas. However, we had problems finding time to work } \\
\text { together. It took more time. }\end{array}$ \\
\hline $\begin{array}{c}\mathrm{C}) \\
(\mathrm{M})\end{array}$ & $\begin{array}{l}\text { I enjoy it. Though we discuss online, we don't have any significant problem. } \\
\text { Sometimes, there is a problem with the network of our mobiles. Besides that, }\end{array}$ \\
\hline
\end{tabular}




\section{Arab World English Journal (AWEJ) Special Issue on Covid 19 Challenges April 2021}

\begin{tabular}{|c|c|}
\hline & $\begin{array}{l}\text { sometimes there are ideas that cannot be conveyed because we don't meet face to } \\
\text { face. However, in terms of the division of tasks, sharing of opinions, and giving } \\
\text { suggestions, we don't have any problem. }\end{array}$ \\
\hline $\begin{array}{l}\mathrm{D} \\
(\mathrm{F})\end{array}$ & $\begin{array}{l}\text { I am happy to collaborate with my partner. We've been through a lot of repeating } \\
\text { sentences, checking them again, and again. Sometimes we have problems with } \\
\text { the network. We feel it difficult, but we are happy. }\end{array}$ \\
\hline $\begin{array}{c}\mathrm{E} \\
(\mathrm{M})\end{array}$ & $\begin{array}{l}\text { I feel happy because I work with a friend I have known before. We can discuss } \\
\text { things and share our opinions comfortably. However, we have a little problem in } \\
\text { deciding the topic, but we have a good discussion about it. }\end{array}$ \\
\hline $\begin{array}{l}\mathrm{F} \\
(\mathrm{F})\end{array}$ & $\begin{array}{l}\text { I feel full of the spirit because there is fun and we can share our own opinions } \\
\text { and combine them. }\end{array}$ \\
\hline $\begin{array}{l}\mathrm{G} \\
(\mathrm{F})\end{array}$ & $\begin{array}{l}\text { It's been a unique experience for me. We discussed things through group chats or } \\
\text { virtual meetings. It's hard to communicate that way because sometimes people } \\
\text { misunderstand us. }\end{array}$ \\
\hline $\begin{array}{l}\mathrm{H} \\
(\mathrm{F})\end{array}$ & $\begin{array}{l}\text { I find it enjoyable, we can share opinions when writing essays. Working with } \\
\text { friends can add relationships and tell each other if there are errors in writing the } \\
\text { essay. }\end{array}$ \\
\hline $\begin{array}{c}\text { I } \\
(\mathrm{F})\end{array}$ & $\begin{array}{l}\text { I feel happy and it helps me to do the assignment. I like it and I'm happy because } \\
\text { now I have a close friend. I feel lonely doing an assignment alone. }\end{array}$ \\
\hline $\begin{array}{c}\mathrm{J} \\
(\mathrm{F})\end{array}$ & $\begin{array}{l}\text { Happy and grateful because I can make a good relationship with my friend } \\
\text { during the collaborative work, I also divided the work with my friend, so we } \\
\text { could finish faster. }\end{array}$ \\
\hline $\begin{array}{l}\mathrm{K} \\
(\mathrm{F})\end{array}$ & $\begin{array}{l}\text { Sometimes there is misunderstanding and confusion in choosing the right words } \\
\text { for our essay, thank God we got feedback from the lecturer, so we can fix our } \\
\text { draft. }\end{array}$ \\
\hline $\begin{array}{l}\mathrm{L} \\
(\mathrm{M})\end{array}$ & I have good discussions with my friend. We always exchange ideas for our tasks. \\
\hline $\begin{array}{l}\mathrm{M} \\
(\mathrm{F})\end{array}$ & $\begin{array}{l}\text { It's very good. I can share my opinions and we can share knowledge and opinions } \\
\text { about the materials and assignments given. }\end{array}$ \\
\hline $\begin{array}{l}\mathrm{N} \\
(\mathrm{F})\end{array}$ & $\begin{array}{l}\text { I have good cooperation with my partner. My partner always did his part fast and } \\
\text { enthusiastically. I have no complaints about him. }\end{array}$ \\
\hline
\end{tabular}

From the online interviews with Student G and Student K on March 1, 2021, both explained that the misunderstanding happened because they used written texts to communicate. Sometimes their partners did not use any punctuations at all which made them unable to get the points. "We just discussed things via WA messages. I did not know my friend's intonation in "speaking". One day, when editing our essay, my partner misunderstood me and edited another part, not the one I asked her to," Student K stated. Student G added, "Maybe if we meet face-toface, the situation would be different. There could be chemistry between us." Further analysis will be presented in the discussion section. 


\section{Arab World English Journal (AWEJ) Special Issue on Covid 19 Challenges April 2021}

Indonesian Freshmen's Challenges in Collaborative Learning during COVID-19

Listyani

\section{Discussion}

As previously mentioned, students were asked to write a reflection in the sixth week of the semester. The answers were summarized in Table one. From Table one, it can be clearly seen that 12 out of 14 students $(85.71 \%)$ felt happy with the collaborative work in writing. Only Student G and Student K (14. 29\%) seemed unhappy with the collaborative work. These two students were good students. They always achieved high in their courses. Unfortunately, their partners in writing happened to be their peer students who were less able than they were. Indeed, this could be a problem when the students working collaboratively were not compatible in terms of proficiency. Andriessen et al. (2003), as cited in Noroozi, Weinberger, Biemans, Mulder, and Mohammad Chizari (2012), mentioned that differences in positions or incompatible views while learners are constructing counter-arguments might potentially trigger socio-cognitive conflicts.

Dealing with time or schedule clash, there is only one participant, Student B, who admitted that he had problems finding the right time with his partner. This is in line with what Tamm (2019) and Anna (2020) stated, that one of the disadvantages of online learning is ELearning requires strong time management skills. Included in time management are the arrangement, organization, making of schedules, and plan. It is about someone's time with the goal of achieving both effective work and output. This also means allocation distribution which is deliberate and the structuring of time among competing demands. All this is based on priority. People cannot store time and its accessibility cannot be enlarged over twenty-four hours (Adebayo \& Omojola, 2015, as cited in Tambaya, 2019).

Four participants, Student E, Student H, Student I, and Student J mentioned that they were happy with the collaborative work since they could make new friends. These students were from the 2020 class year who never met face-to-face before. For them, it was a special blessing to have new friends and they could get close to these new partners. Student I showed her contentment dealing with this matter, "I feel happy and it helps me to do the assignment. I like it and I'm happy because now I have a close friend. I feel lonely to do an assignment alone."

Getting a chance to share knowledge is another reason for liking collaborative learning. As many as seven students (50\%) felt glad because they could share knowledge as well as opinions with their partners. These are Student B, Student C, Student E, Student F, Student H, Student L, and Student M. This was also stated by Hedge (2000). She mentioned that that anytime students of different performance levels work together in one group, they will be responsible for their peers' learning process instead of merely accountable for their own interests. In collaborative learning, the ideas and information shared by the students are a valuable learning source for every student in the class.

There is another opinion of the participant dealing with English structure. One student mentioned that she was helped in terms of grammar. This was stated by Student D, "I am happy to collaborate with my partner. We've been through a lot of repeating sentences, checking them again, and again. Sometimes we have problems with the network. We feel it difficult, but we are happy." A study conducted by Ghorbani \& Nezamoshari'e (2012) on 62 female freshmen majoring in different fields like Law, Accounting, and Economics at Ashkhane Distance Learning University, Ashkhane, Iran, also found that collaborative learning improved both high as well as low achievers. All these respondents were native speakers of Persian. 


\section{Arab World English Journal (AWEJ) Special Issue on Covid 19 Challenges April 2021}

Problems with the cellular network were experienced by Student A, Student C, and Student D. This is a very common problem experienced by many students who are doing online learning. Caballé, Xhafa, and Barolli (2021) asserted that modern mobile collaborative learning environments have to provide advanced enablement for the distribution of learning activities. The necessary functionalities and learning resources should also be provided to all participants, regardless of where the participants and resources are located, and whether this location is static or dynamic. However, all the participants in this present study stayed in their hometowns all over Indonesia. In some parts, internet network availability was still unstable. Dealing with internet data plans, Efriana (2021) explained that even though the internet is in students' hands, they still face difficulty accessing the internet network because of the areas where they live. A study conducted by Nashruddin, Alam, and Tanasy (2020), as cited in Efriana (2021), found that some students live in remote rural areas which are not covered by the internet. In addition, their cellular network is sometimes unstable. This is caused by the geographical location which is far from the signal coverage. This becomes a problem that happens to many students who take online learning. This results in less effective implementation of online learning.

Besides data from the reflections, four students were also interviewed. From Participants $\mathrm{E}, \mathrm{J}, \mathrm{H}$, and I's answers about friendship, it could be seen that collaborative work can become a kind of "platform" for these freshmen to make friends. This is in line with a study done by Pattanpichet (2011). He found a surprising fact that working in groups can grow familiarity and friendships among students. When collaborative learning is used in large classrooms such as arranging students into group work, it helps to create a "knowledge-sharing atmosphere". With the help of collaborative learning, students also learn to work in a team, and this can help in developing their social skills for the work environment in the future.

\section{Conclusion}

As previously mentioned, there is only one research question addressed in this study, that is, What challenges do Procedural Writing students experience in doing collaborative learning during the pandemic COVID 19? From the discussion above, there are several conclusions that can be drawn. First, in both online and offline situations, collaborative learning is necessary to build students' soft skills. They can learn to share ideas, opinions, knowledge, as well as information. Besides that, they could learn to express their opinions, argue, accept, and negotiate others' opinions with good mannerism. Secondly, collaborative learning is good to build good relationships between and among students. EFL teachers should think of various ways of assigning students to do collaborative activities including group and pair work.

There are however some limitations of this current study. This study was limited in the number of participants. Future researchers can have more participants involving more students and employing more research instruments for data triangulation. Future studies can also be conducted on different levels of writing classes with different levels of students like semaphores or third-year students. This study hopefully can add useful insights both for teachers and students of writing in general, particularly of Procedural Writing class.

The pedagogical implications of this study are stated as follows. It is time that EFL teachers, not only at the tertiary level but also at the secondary level, think of online collaborative activities which are suitable for their students. All activities should ideally be 


\section{Arab World English Journal (AWEJ) Special Issue on Covid 19 Challenges April 2021}

adjusted with the students' condition and proficiency level. The idea is to make students learn from one another during this pandemic without any pressure. The group should work together for the betterment of all group members. It is just like what Phil Jackson mentions, "The strength of the team is each individual member. The strength of each member is the team" (Alexander, 2017, p. 1).

\section{About the Author:}

Listyani has been a lecturer at ELEP/ PBI, FLA/ FBS, UKSW, Indonesia, since March 1999. In August 2017, she got her Doctorate degree from UNNES Indonesia, majoring in English Language Education. In November 2020, she got her professorship from the Indonesian Government, majoring in the same field. ORCiD ID:http://orcid.org/0000-0002-3284-9434

\section{References}

lexander, M. (2017). 60 quotes to inspire collaboration in the new year. Retrieved from https://blog.mavenlink.com/60-quotes-to-inspire-collaboration-in-the-new-year

Anna. (2020). Our top 5 advantages and disadvantages of online learning. Retrieved from https://www.easy-lms.com/knowledge-center/lms-knowledge-center/advantages-anddisadvantages-of-online-learning/item 12529

Berg, G.V.D. (2019). How important is interaction to students? A case study in open distance learning. Retrieved from http://web.b.ebscohost.com/ehost/pdfviewer/pdfviewer?vid=4\&sid=427c3ef3-db594417-b19e-910a42affade\%40sessionmgr103

Bishnoi, N. (2017). Collaborative learning: A learning tool advantages and disadvantages. Indian Journal of Health and Well-being, 8(8), 850-852.

Caballé, S., Xhafa, F., \& Barolli, L. (2021). Using mobile devices to support online collaborative learning. Retrieved from:

https://www.researchgate.net/publication/220056796_Using_Mobile_Devices_to_Suppor t_Online_Collaborative_Learning

Campbell, J., \& Li, M. (2006). Asian students' perceptions of group work and group assignments in a New Zealand tertiary institution. Proceedings of EDU-COM International Conference (pp. 78-89). Perth Western Australia: Edith Cowan University. Retrieved from http://ro.ecu.edu.au/ceducom/64

Cinganotto, L. (2019). Online interaction in teaching and learning a foreign language: an Italian pilot project on the companion volume to the CEFR. Je-LKS Pre-Reviewed Papers Embracing language awareness and language diversity in the $21^{\text {st }}$ century, 5(1), 136152. Retrieved from http://web.b.ebscohost.com/ehost/pdfviewer/pdfviewer?vid=13\&sid=40287c75-e8b0440a-b195-bf14b340209b\%40pdc-v-sessmgr04

Efriana, L. (2021). Problems of Online Learning during Covid-19 Pandemic in EFL Classroom and the Solution. JELITA: Journal of English Language Teaching and Literature, 2(1), 38-47.

ELEP, UKSW. (Producer). (2021). Procedural Writing Handbook. Salatiga: ELEP, UKSW. Ghorbani, M.R. \& Nezamoshari'e, M. Cooperative Learning Boosts EFL Students' Grammar Achievement University of Bojnord, Bojnord, Iran. Theory and Practice in Language 
Arab World English Journal (AWEJ) Special Issue on Covid 19 Challenges April 2021

Indonesian Freshmen's Challenges in Collaborative Learning during COVID-19

Listyani

Studies, 2(7), 1465-1471. Retrieved from

http://www.academypublication.com/issues/past/tpls/vol02/07/18.pdf

Hameed, Y., Taiar, H.A., O'Leary, D., \& Kaynge, L. (2018). Can Online Distance Learning improve access to learning in conflict zones? The Oxford Psychiatry in Iraq (OxPIQ) Experience. British Journal of Medical Practitioners, 11(2), 19-26. Retrieved from http://web.b.ebscohost.com/ehost/pdfviewer/pdfviewer?vid=5\&sid=427c3ef3-db594417-b19e-910a42affade\%40sessionmgr103

Hedge, T. (2000). Teaching and learning in the language classroom. Oxford: Oxford University Press.

Higley, M. (2018). Reasons why collaborative online learning activities are effective. Retrieved from https://elearningindustry.com/collaborative-online-learning-activities-reasons-effective

Laal, M., \& Ghodsi, S. M. (2012). Benefits of collaborative learning. Procedia - Social and Behavioral Science. 31,486-490. doi:10.1016/j.sbspro.2011.12.091.

McLeod, S. (2019). Constructivism as a theory for teaching and learning. Retrieved from https://www.simplypsychology.org/constructivism.html

Noroozi, O., Weinberger, A., Biemans, H.J.A., Mulder, M., and Chizari, M. (2012). Argumentation-Based Computer-Supported Collaborative Learning (ABCSCL): A synthesis of 15 years of research. Educational Research Review, 7(12), 79-106. Retrieved from https://www.mmulder.nl/wp-content/uploads/2011/11/Noroozi-2012-

Argumentation-based-computer-supported-collaborative-learning-ABCSCL.pdf

Omar, N.D., Hassan, H., \& Atan, H. (2012). Student engagement in online learning: Learners attitude toward E-Mentoring. Procedia - Social and Behavioral Sciences, 67, $464-475$. Retrieved from https://www.researchgate.net/publication/257718366_Student_Engagement_in_Online_L earning_Learners_Attitude_Toward_E-Mentoring

Overtoom, C. (2001). Employability skills: An update. 20-35 35.

Pattanpichet, F. (2011). The effects of using collaborative learning to enhance students' English speaking achievement. Journal of College Teaching \& Learning, 8(11), 1-10. Retrieved from https://eric.ed.gov/?id=EJ952409

Purarjomandlangrudi, A., \& Chen, D. (2019). A causal loop approach to uncover interrelationship of student online interaction and engagement and their contributing factors. Research in Learning Technology, 27, 1-16. Retrieved from http://dx.doi.org/10.25304/rlt.v27.2058

Song, D., Rice, M., \& Oh, E.Y. (2019). Participation in Online Courses and Interaction With a Virtual Agent. International Review of Research in Open and Distributed Learning, 20(1), 43-63. Retrieved from http://web.b.ebscohost.com/ehost/pdfviewer/pdfviewer?vid=8\&sid=40287c75-e8b0440a-b195-bf14b340209b\%40pdc-v-sessmgr04

Tambaya, L. (2019). Relationship between examination anxiety and time management among university students. Master's thesis. Near East University Graduate School of Social Sciences General Psychology Program. Nicosia. Retrieved from http://docs.neu.edu.tr/library/6727597846.pdf

Tamm, S. (2019). The disadvantages of E-Learning. Retrieved from https://e-student.org/disadvantages-of-e-learning/ 